\title{
The Influence of Mycorrhizal Fungi on the Growth of Apple and Sour Cherry Maidens Fertilized with Different Bioproducts in the Organic Nursery
}

\author{
Zygmunt S. Grzyb ${ }^{1}$, Lidia Sas Paszt ${ }^{1}$, Wojciech Piotrowski ${ }^{1}$ and Eligio Malusa ${ }^{2}$ \\ 1. Department of Pomology, Research Institute of Horticulture, Konstytucji 3 Maja 1/3, Skierniewice 96-100, Poland \\ 2. CRA-Center for Plant Soil Systems. Livorno 58, Torino 10100, Italy
}

Received: May 1, 2015 / Accepted: May 14, 2015 / Published: May 30, 2015.

\begin{abstract}
Apple/Malus $x$ domestica cv. 'Topaz'/M26 and sour cherry cv. 'Debreceni Bötermö'/Prunus mahaleb L. maidens were fertilized with different organic fertilizers and soil amendments in an organic nursery. A mycorrhizal inoculant, Micosat, was added to the non-fertilized control and to combinations fertilized with various bioproducts. Under assessment was the effect of nutrient delivery on the growth and development of maiden fruit trees focussing on tree height, thickness of the tree trunk, the number and the length of lateral shoots in each treatment combination. It was found that the introduction of mycorrhizal fungi into the soil without fertilizer application significantly improved the growth and development of apple and sour cherry maidens. Mineral fertilizer application (NPK) combined with mycorrhizal inoculation had a negligible effect on the above features. In the presence of bioproducts such as granular manure, Humus Active + Aktywit PM, BF Amin, Vinassa and Florovit Eko, the mycorrhizal fungi were more biologically active than in the absence of these products.
\end{abstract}

Key words: Biopreparation, fertilization, maiden fruit tree, mycorrhiza, ecological nursery.

\section{Introduction}

Lack of detailed information on the impact of traditional organic fertilization with manure and very few data on new organic fertilizers, plant extracts, and bacterial and mycorrhizal inocula are real obstacles to the development of innovative technologies of cultivation and fertilization of plants in the agricultural sector $[1,2]$.

Mycorrhizal fungi live in symbiosis with the majority of plants growing in the wild as well as with cultivated crops. The symbiosis generally results in an increase in the uptake of minerals $(\mathrm{P}, \mathrm{N}, \mathrm{Mg}, \mathrm{K}$, and microelements) by plants and higher crop yields, promotes vigorous growth of plants and makes them more resistant to environmental stresses, such as water

Corresponding author: Zygmunt S. Grzyb, Dr., Prof. in pomology, research fields: ecology, nursery, gene resources, stone fruits. E-mail: Zygmunt.Grzyb@inhort.pl. deficit or excessive overheating of the substrate [3, 4]. There are, however, examples of reverse action, in which some species of plants eliminate or inhibit the biological activity of mycorrhizal fungi. To a large extent, this effect often depends on the type of agrotechnical treatments, plant species and cultivar, soil fertility and degree of acidification, planting density, soil temperature, and the cultivation system $[2,5]$.

Application of mycorrhizal inocula can increase species diversity of mycorrhizal fungi in the rhizosphere and consequently improve the growth, yield and yield quality of cultivated fruit crops $[6,7]$. Determination of the optimal conditions for the coexistence of a plant and symbiotic fungi is key to obtaining positive effects of mycorrhization [5].

Most of the attention has been focused on the influence of mycorrhiza on the growth and fruiting of strawberry plants [2, 8-10]. 
New products for improving soil fertility and technologies being introduced into organic production are studied in detail also in terms of their effect on the behaviour of soil microorganisms [2]. Numerous forms of organic fertilizers and soil conditioners have been evaluated by many authors, both on herbaceous and woody plants [11-14]. Soil enrichment with organic bioproducts containing beneficial microorganisms, including bacteria and mycorrhizal fungi, provides a real opportunity for improving the growth and fruiting of plants [1, 15-16]. The evidence for this are recent studies of fruit trees grown by organic methods in nurseries [13, 17-19].

The aim of the present study was to assess the biological effects of mycorrhizal fungi used in an organic nursery of fruit trees in combination with various bioproducts containing nutrients and active substances (i.e. plant hormone-like substances, enzymes) to more intensively stimulate the growth and development of maiden fruit trees.

\section{Materials and Methods}

The study was conducted in 2011-2013 in an experimental nursery located in Mokra Lewa, near Skierniewice, central Poland. However, this paper presents only the results from the two years (2011-2012) of the study, because since the very wet weather of 2013 caused more than 50\% mortality among the experimental trees. The soil in which the trees grew was a podzolic soil. Soil analysis showed the $\mathrm{pH}$ of 6.1 , and the mineral content at following levels: $\mathrm{N}(0.07 \% \mathrm{ADW}), \mathrm{K}(6.7 \mathrm{mg} / 100 \mathrm{~g}$ of soil $), \mathrm{P}$ (3.9 mg/100 g of soil), $\mathrm{Mg}$ (3.4 mg/100 g of soil) [20].

Rootstocks were planted every $25.0 \mathrm{~cm}$ within the row and $1.0 \mathrm{~m}$ between rows. For three consecutive years before establishing the nursery, cereal crops had been grown, and in the year preceding the planting of rootstocks, mustard plants had been ploughed in as green manure. The experiment was set up in a randomized block design with four replications, each repetition had 10 plants. In the first year (2010-2012) of running the nursery, the treatments were applied to cherry rootstocks (Prunus mahaleb L.) and to M 26 apple rootstocks [21]. In the second years (2011-2013), rootstocks were grafting by chip budding method, with using such cultivars as "Debreceni Bötermö" for sour cherry and to apple-“Topaz".

The following treatments were applied:

(1) No treatment (control);

(2) Micosat F12 WP (CCS Aosta Srl, Italy) - microbial inoculum consisting of mycorrhizal fungi (Glomus mosseae and G. intraradices) and plant growth promoting bacteria (Pseudomonas fluorescence and Bacillus subtilis strains). The product contains $40 \% \mathrm{C}, 0.15 \% \mathrm{~N}, 431 \mathrm{mg} \cdot \mathrm{kg}^{-1} \mathrm{P}$ and $9,558 \mathrm{mg} \cdot \mathrm{kg}^{-1} \mathrm{~K}$, and has a granular consistency. Micosat was applied to the soil at a dose of $10 \mathrm{~g} \cdot \mathrm{m}^{-2}$ (100 kg.ha $\left.{ }^{-1}\right)$ at planting;

(3) Chemical NPK application at a dose of 17.64 $\mathrm{g} \cdot \mathrm{m}^{-2} \mathrm{NH}_{4} \mathrm{NO}_{3}, 6.52 \mathrm{~g} \cdot \mathrm{m}^{-2}$ triple super phosphate, and $16.0 \mathrm{~g} \cdot \mathrm{m}^{-2} \mathrm{~K}_{2} \mathrm{SO}_{4}$, equivalent to $60 \mathrm{~kg} \cdot \mathrm{ha}^{-1} \mathrm{~N}, 30$ $\mathrm{kg} \cdot \mathrm{ha}^{-1} \mathrm{P}$, and $80 \mathrm{~kg} \cdot \mathrm{ha}^{-1} \mathrm{~K}$;

(4) Fertigo (Ferm-O-Feed, the Netherlands) - granulated manure containing 55\% C, $1 \% \mathrm{~N}, 0.3 \% \mathrm{P}$ and $1 \% \mathrm{~K}$; besides these, also microelements and soil micro-organisms. The product was applied at a dose of $150 \mathrm{~g} \cdot \mathrm{m}^{-2}\left(1500 \mathrm{~kg} \cdot \mathrm{ha}^{-1}\right)$, equivalent to $45 \mathrm{~kg} \cdot \mathrm{ha}^{-1} \mathrm{~N}, 13 \mathrm{~kg} \cdot \mathrm{ha}^{-1} \mathrm{P}$ and $17 \mathrm{~kg} \cdot \mathrm{ha}^{-1} \mathrm{~K}$;

(5) Humus UP (Ekodarpol, Poland) - an extract from vermicomposts, containing $0.65 \% \mathrm{C}, 0.03 \% \mathrm{~N}$, $30.8 \mathrm{mg} \cdot \mathrm{kg}^{-1} \mathrm{P}$ and $4,535 \mathrm{mg} \cdot \mathrm{kg}^{-1} \mathrm{~K}$. The product was applied to the soil as a $2 \%$ solution $\left(2 \mathrm{~mL} \cdot \mathrm{m}^{-2}\right)$ $\left(20 \mathrm{~L} \cdot \mathrm{ha}^{-1}\right)$;

(6) Humus Active + Aktywit PM (Ekodarpol, Poland) - an extract from vermicomposts based on a product derived from molasses. Humus Active is a soil improver with active humus and population of beneficial microorganisms, containing $0.78 \% \mathrm{C}$, $0.03 \% \mathrm{~N}, 1,050 \mathrm{mg} \cdot \mathrm{kg}^{-1} \mathrm{P}$ and $4,119 \mathrm{mg} \cdot \mathrm{kg}^{-1} \mathrm{~K}$. Aktywit PM is a soil improver containing $20.5 \% \mathrm{C}$, $0.92 \% \mathrm{~N}, 81.2 \mathrm{mg} \cdot \mathrm{kg}^{-1} \mathrm{P}$ and $42,990 \mathrm{mg} \cdot \mathrm{kg}^{-1} \mathrm{~K}$. (Humus Active was applied to the soil as a $2 \%$ 
solution $\left(2 \mathrm{~mL} \cdot \mathrm{m}^{-2}\right)\left(20 \mathrm{~L}^{-h^{-1}}\right)$, and Aktywit PM was applied to the soil as a $1 \%$ solution $-1 \mathrm{~mL} \cdot \mathrm{m}^{-2}(10$ $\left.\mathrm{L} \cdot \mathrm{ha}^{-1}\right)$ );

(7) BioFeed Quality (Agrobio Products B.V., the Netherlands) - an extract from several seaweed species reinforced with humic and fulvic acids, containing $0.6 \% \quad \mathrm{C}, \quad 0.07 \% \mathrm{~N}, \quad 32.6 \mathrm{mg} \cdot \mathrm{kg}^{-1} \mathrm{P}$, applied to the soil as a $0.5 \%$ solution $\left(0.5 \mathrm{~mL} \cdot \mathrm{m}^{-2}\right)$ $\left(5 \mathrm{~L} \cdot h a^{-1}\right)$;

(8) BioFeed Amin (Agrobio Products B.V., the Netherlands) - an extract of vegetal amino acids, containing $1.12 \% \mathrm{C}, 0.14 \% \mathrm{~N}, 347 \mathrm{mg} \cdot \mathrm{kg}^{-1} \mathrm{P}$. The product was applied to the soil as a $0.5 \%$ solution $(0.5$ $\left.\mathrm{mL} \cdot \mathrm{m}^{-2}\right)\left(5 \mathrm{~L}^{\mathrm{h}} \mathrm{ha}^{-1}\right)$;

(9) Vinassa (Józefów, Limited Liability Company, Poland)-molasses residue from yeast production, containing $12.0 \% \mathrm{C}, 1.86 \% \mathrm{~N}, 949 \mathrm{mg} \cdot \mathrm{kg}^{-1} \mathrm{P}, 17,615$ $\mathrm{mg} \cdot \mathrm{kg}^{-1} \mathrm{~K}$. The product was applied to the soil as a $0.5 \%$ solution $\left(0.5 \mathrm{~mL} \cdot \mathrm{m}^{-2}\right)\left(5 \mathrm{~L} \cdot \mathrm{ha}^{-1}\right)$;

(10) Florovit Eko (Inco-Veritas, Poland) - product contains lignite, potassium sulphate $(5 \% \mathrm{~K})$, phosphorus $(3 \% \mathrm{P})$, dolomite, bentonite, and molasses. It was applied to the soil at $150 \mathrm{~g} \cdot \mathrm{m}^{-2}\left(1,500 \mathrm{~kg} \cdot \mathrm{ha}^{-1}\right)$.

All the preparations except for Micosat, NPK and granulated manure (Fertigo) were applied twice during the growing season: the first time in the rootstock nursery at the end of May when the rootstocks started active growth, and again in the middle of June. Similar, the following year: first in the nursery of maiden trees in mid-May and again at the beginning of June. Micosat was applied to the soil by hand to a depth of about $15 \mathrm{~cm}$. Following application of the preparations, the soil around the plants was thoroughly mixed using hand hoes each time. Protection of plants against pests and diseases was carried out by means approved for use in organic farming, and weeds were destroyed mechanically.

In the autumn, before digging up the trees from the nursery, measurements of their trunk diameter at a height of $30 \mathrm{~cm}$ aboveground and of their height were taken; the number of branched trees and the length and number of lateral shoots were recorded. Only the lateral shoots longer than $3 \mathrm{~cm}$ were included in the measurements.

The data obtained were processed statistically using a two-way analysis of variance for a randomized block design. Multiple comparisons of the means for the combinations were performed with Tukey's test at a significance level of $P=0.05$.

\section{Results}

The effects of the use of organic fertilizers and mycorrhizal fungi on the morphology of apple and sour cherry maidens are shown in Tables 1-4.

Micosat applied to the soil in 2011 in the control combination with apple maidens that had not been previously fertilized gave significantly increased the trunk diameter (Table 1). Micosat in combination with NPK application had no effect on the above parameter A significant increase in the trunk diameter of apple maiden trees under the influence of Micosat was found after fertilizing them with the preparations of Humus Active + Aktywit PM, Vinassa, and Florovit Eko. Micosat had a significant effect on the height of the maidens only in the combinations where Humus Active + Aktywit PM and Vinassa were used for fertilization. The effect of Micosat on the number of branched maidens was not significant. The preparation increased the number of lateral shoots in maiden apple trees in all the combinations of organic fertilization. By contrast, when combined with mineral fertilization, Micosat gave a worse result than fertilization with NPK only. Micosat significantly increased the total length of lateral shoots of maiden apple trees only where Florovit Eko was used.

In the second year of the study (Table 2), Micosat had no effect on the trunk diameter of maiden apple trees, but was found to stimulate significantly their growth in height. In combination with Fertigo manure, Humus UP, BF Quality, BF Amin and Vinassa, the mycorrhizal preparation had also a favourable effect on the growth of the apple maidens. However under 
Table 1 Effect of various fertilization treatments on plant growth parameters of apple cv. "Topaz" maiden trees grown in an organic nursery, 2011.

\begin{tabular}{|c|c|c|c|c|c|}
\hline Treatment & $\begin{array}{l}\text { Trunk diameter } \\
\mathrm{mm}\end{array}$ & $\begin{array}{l}\text { Tree height } \\
\mathrm{cm}\end{array}$ & $\begin{array}{l}\text { Number of } \\
\text { branched trees } \\
\%\end{array}$ & $\begin{array}{l}\text { Number of } \\
\text { lateral shoots }\end{array}$ & $\begin{array}{l}\text { Total length of } \\
\text { lateral shoots } \\
\mathrm{cm}\end{array}$ \\
\hline Control** & $10.5 \mathrm{a}^{*}$ & $97 \mathrm{a}$ & $91.5 \mathrm{a}$ & $3.2 \mathrm{ab}$ & $17 \mathrm{a}$ \\
\hline Micosat & $12.4 \mathrm{e}-\mathrm{g}$ & $106 a-c$ & $90.0 \mathrm{a}$ & $4.0 \mathrm{c}-\mathrm{f}$ & $15 \mathrm{a}$ \\
\hline NPK & 13.4hi & $106 a-c$ & $99.5 \mathrm{a}$ & 5.4hi & $99 \mathrm{~h}$ \\
\hline NPK + Micosat & $12.0 \mathrm{c}-\mathrm{f}$ & $111 b-e$ & $90.0 \mathrm{a}$ & 3.6a-d & $15 \mathrm{a}$ \\
\hline Fertigo Manure & $12.9 \mathrm{f}-\mathrm{h}$ & $113 b-f$ & $97.3 \mathrm{a}$ & $4.3 \mathrm{~d}-\mathrm{f}$ & $58 \mathrm{de}$ \\
\hline Fertigo Manure + Micosat & $14.3 \mathrm{j}$ & $118 \mathrm{~d}-\mathrm{f}$ & $88.8 \mathrm{a}$ & $5.5 \mathrm{hi}$ & $49 b c$ \\
\hline Humus UP & $13.1 \mathrm{~g}-\mathrm{i}$ & $121 \mathrm{e}-\mathrm{g}$ & $99.8 \mathrm{a}$ & $3.4 \mathrm{a}-\mathrm{c}$ & $61 \mathrm{ef}$ \\
\hline Humus UP + Micosat & $11.4 \mathrm{~b}-\mathrm{d}$ & $122 \mathrm{fg}$ & $84.5 \mathrm{a}$ & $5.3 g-i$ & $58 \mathrm{de}$ \\
\hline Humus Active + Aktywit PM & $11.4 \mathrm{~b}-\mathrm{d}$ & $116 c-f$ & $100 \mathrm{a}$ & $3.5 \mathrm{a}-\mathrm{c}$ & $51 \mathrm{~cd}$ \\
\hline Humus Active + Aktywit PM + Micosat & $12.5 \mathrm{e}-\mathrm{g}$ & $134 \mathrm{~h}$ & $90.0 \mathrm{a}$ & $5.5 \mathrm{hi}$ & $49 b c$ \\
\hline BF Quality & $11.0 \mathrm{ab}$ & $114 c-f$ & $98.5 \mathrm{a}$ & $3.1 \mathrm{a}$ & $41 b$ \\
\hline BF Quality + Micosat & $10.8 \mathrm{ab}$ & $111 b-f$ & $89.8 \mathrm{a}$ & $6.0 \mathrm{ij}$ & $48 \mathrm{bc}$ \\
\hline BF Amin & $12.1 \mathrm{~d}-\mathrm{f}$ & $109 b-d$ & $100 \mathrm{a}$ & $5.2 \mathrm{~g}-\mathrm{i}$ & $69 f$ \\
\hline BF Amin + Micosat & $11.2 \mathrm{a}-\mathrm{c}$ & $103 \mathrm{ab}$ & $92.5 \mathrm{a}$ & $4.8 \mathrm{f}-\mathrm{h}$ & $58 \mathrm{de}$ \\
\hline Vinassa & $12.2 \mathrm{~d}-\mathrm{f}$ & $117 \mathrm{~d}-\mathrm{f}$ & $99.3 \mathrm{a}$ & $3.9 \mathrm{~b}-\mathrm{e}$ & $47 \mathrm{bc}$ \\
\hline Vinassa + Micosat & $13.9 \mathrm{ij}$ & $130 \mathrm{gh}$ & $93.5 \mathrm{a}$ & $5.6 \mathrm{i}$ & $48 \mathrm{bc}$ \\
\hline Florovit Eko & $11.9 \mathrm{c}-\mathrm{e}$ & $138 \mathrm{~h}$ & $100 \mathrm{a}$ & $4.6 \mathrm{e}-\mathrm{g}$ & $54 \mathrm{c}-\mathrm{e}$ \\
\hline Florovit Eko + Micosat & $13.6 \mathrm{~h}-\mathrm{j}$ & $136 \mathrm{~h}$ & $97.3 \mathrm{a}$ & $6.5 \mathrm{j}$ & $83 \mathrm{~g}$ \\
\hline
\end{tabular}

\#- shoots longer than $3 \mathrm{~cm}, * *$ - control (no fertilization); *-values that do not differ from each other are designated in each column by the same letters, according to Tukey's test at a significance level of $\mathrm{P}=0.05$.

Table 2 Effect of various fertilization treatments on plant growth parameters of apple cv. "Topaz" maiden trees grown in an organic nursery, 2012.

\begin{tabular}{llllll}
\hline Treatment & $\begin{array}{l}\text { Trunk } \\
\text { diameter } \\
\mathrm{mm}\end{array}$ & $\begin{array}{l}\text { Tree height } \\
\mathrm{cm}\end{array}$ & $\begin{array}{l}\text { Number of } \\
\text { branched trees } \\
\%\end{array}$ & $\begin{array}{l}\text { Number of lateral } \\
\text { shoots }^{\#}\end{array}$ & $\begin{array}{l}\text { Total length of } \\
\text { lateral shoots } \\
\mathrm{cm}^{\#}\end{array}$ \\
\hline Control** & $10.0 \mathrm{a} *$ & $84 \mathrm{a}$ & $81.8 \mathrm{a}$ & $2.1 \mathrm{a}$ & $13 \mathrm{a}$ \\
Micosat & $11.0 \mathrm{a}$ & $94 \mathrm{~b}$ & $95.0 \mathrm{~b}$ & $5.1 \mathrm{f}-\mathrm{h}$ & $41 \mathrm{~d}$ \\
NPK & $13.1 \mathrm{a}$ & $103 \mathrm{~cd}$ & $97.5 \mathrm{~b}$ & $3.2 \mathrm{ab}$ & $23 \mathrm{bc}$ \\
NPK + Micosat & $13.2 \mathrm{a}$ & $98 \mathrm{bc}$ & $93.8 \mathrm{~b}$ & $3.7 \mathrm{~b}-\mathrm{d}$ & $27 \mathrm{c}$ \\
Fertigo Manure & $12.7 \mathrm{a}$ & $106 \mathrm{de}$ & $98.8 \mathrm{~b}$ & $3.3 \mathrm{bc}$ & $22 \mathrm{bc}$ \\
Fertigo Manure + Micosat & $13.7 \mathrm{a}$ & $114 \mathrm{f}-\mathrm{h}$ & $95.0 \mathrm{~b}$ & $4.6 \mathrm{~d}-\mathrm{f}$ & $44 \mathrm{~d}$ \\
Humus UP & $11.9 \mathrm{a}$ & $107 \mathrm{~d}-\mathrm{f}$ & $99.8 \mathrm{~b}$ & $3.8 \mathrm{~b}-\mathrm{e}$ & $41 \mathrm{~d}$ \\
Humus UP + Micosat & $12.2 \mathrm{a}$ & $114 \mathrm{gh}$ & $99.3 \mathrm{~b}$ & $5.8 \mathrm{gh}$ & $39 \mathrm{~d}$ \\
Humus Active + Aktywit PM & $11.5 \mathrm{a}$ & $103 \mathrm{~cd}$ & $99.5 \mathrm{~b}$ & $3.0 \mathrm{ab}$ & $20 \mathrm{ab}$ \\
Humus Active + Aktywit PM + Micosat & $11.4 \mathrm{a}$ & $104 \mathrm{~cd}$ & $95.8 \mathrm{~b}$ & $5.1 \mathrm{f}-\mathrm{h}$ & $39 \mathrm{~d}$ \\
BF Quality & $13.2 \mathrm{a}$ & $107 \mathrm{de}$ & $100 \mathrm{~b}$ & $4.4 \mathrm{c}-\mathrm{f}$ & $97 \mathrm{~h}$ \\
BF Quality + Micosat & $13.6 \mathrm{a}$ & $112 \mathrm{e}-\mathrm{g}$ & $99.8 \mathrm{~b}$ & $6.1 \mathrm{~h}$ & $65 \mathrm{f}$ \\
BF Amin & $13.1 \mathrm{a}$ & $103 \mathrm{~cd}$ & $100 \mathrm{~b}$ & $5.0 \mathrm{e}-\mathrm{g}$ & $52 \mathrm{e}$ \\
BF Amin + Micosat & $13.9 \mathrm{a}$ & $120 \mathrm{~h}$ & $100 \mathrm{~b}$ & $5.9 \mathrm{gh}$ & $63 \mathrm{f}$ \\
Vinassa & $13.5 \mathrm{a}$ & $107 \mathrm{~d}-\mathrm{f}$ & $100 \mathrm{~b}$ & $3.0 \mathrm{ab}$ & $24 \mathrm{bc}$ \\
Vinassa + Micosat & $14.0 \mathrm{a}$ & $116 \mathrm{gh}$ & $99.5 \mathrm{~b}$ & $4.0 \mathrm{~b}-\mathrm{f}$ & $37 \mathrm{~d}$ \\
Florovit Eko & $13.3 \mathrm{a}$ & $106 \mathrm{de}$ & $100 \mathrm{~b}$ & $3.1 \mathrm{ab}$ & $40 \mathrm{~d}$ \\
Florovit Eko + Micosat & $13.7 \mathrm{a}$ & $107 \mathrm{~d}-\mathrm{f}$ & $99.3 \mathrm{~b}$ & $7.5 \mathrm{i}$ & $75 \mathrm{~g}$ \\
\hline Ex & & & &
\end{tabular}

Explanations the same as below Table 1. 
NPK mineral fertilization it tended to inhibit growth. The number of branched maidens increased under the influence of Micosat only when compared to the control. Micosat significantly stimulated the number of lateral shoots of maiden apple trees except to NPK mineral fertilizer combination, Fertigo manure and Vinassa preparations. Micosat favourably affected the total length of lateral shoots not only in the combination where it was applied alone, but also where Fertigo granular manure and the preparations BF Amin, Vinassa and Florovit Eko were used. However, in combination with the preparation $\mathrm{BF}$ Quality, its presence was of no significance for plant growth.

In sour cherry, in 2011, Micosat stimulated tree trunk diameter growth in all the experimental combinations except for Humus UP and BF Quality (Table 3). A significant increase in the height of maidens in Micosat presence was observed in all fertilization combinations except for those with NPK and Florovit Eko. However, Micosat had no effect on the number of branched trees in the nursery. In the combination where NPK was used to fertilize sour cherry maidens, Micosat did not enhance the formation of lateral shoots. A significant increase in the number of lateral shoots associated with its presence was found only where the maidens were fertilized with Fertigo manure and preparations $\mathrm{BF}$ Amin and Vinassa. A significant increase in the total length of lateral shoots was observed under Micosat treatment as well as in all the combinations of organic fertilization involving this product with exception to Humus UP and NPK mineral fertilization.

In 2012, Micosat stimulated growth in thickness of the trunk of sour cherry maidens. When combined with BF Amin it also had a positive effect on tree trunk diameter. In NPK-fertilized plots, growth of the maidens was the same as control trees (Table 4). Weaker growth (tree height) under Micosat treatment was observed when fertilization was with NPK and with the organic preparations Humus UP, BF Quality and Vinassa. Micosat had no effect on the number of

Table 3 Effect of various fertilization treatments on plant growth parameters of sour cherry cv. "Debreceni Bötermö" maiden trees grown in an organic nursery, 2011.

\begin{tabular}{|c|c|c|c|c|c|}
\hline Treatment & $\begin{array}{l}\text { Trunk diameter } \\
\mathrm{mm}\end{array}$ & $\begin{array}{l}\text { Tree height } \\
\mathrm{cm}\end{array}$ & $\begin{array}{l}\text { Number of } \\
\text { branched trees } \\
\%\end{array}$ & $\begin{array}{l}\text { Number of } \\
\text { lateral shoots }^{\#}\end{array}$ & $\begin{array}{l}\text { Total length of } \\
\text { lateral shoots } \\
\mathrm{cm}\end{array}$ \\
\hline Control** & $13.3 \mathrm{a}$ & $124 \mathrm{a}$ & $97.0 \mathrm{a}$ & $4.0 \mathrm{a}$ & $191 \mathrm{a}$ \\
\hline Micosat & $15.9 \mathrm{de}$ & $141 b c$ & $100 \mathrm{a}$ & $5.5 b-d$ & $309 j$ \\
\hline NPK & $15.1 b-d$ & $148 \mathrm{c}-\mathrm{f}$ & $100 \mathrm{a}$ & $6.0 \mathrm{~d}-\mathrm{f}$ & $280 f g$ \\
\hline NPK + Micosat & $15.9 \mathrm{de}$ & $151 d-f$ & $99.8 \mathrm{a}$ & $5.1 \mathrm{bc}$ & $271 \mathrm{ef}$ \\
\hline Fertigo Manure & $14.8 \mathrm{bc}$ & $142 b-d$ & $100 \mathrm{a}$ & $6.0 \mathrm{~d}-\mathrm{f}$ & $239 c$ \\
\hline Fertigo Manure + Micosat & $17.7 \mathrm{~g}$ & $163 \mathrm{gh}$ & $100 \mathrm{a}$ & $7.4 \mathrm{~g}$ & $388 \mathrm{~m}$ \\
\hline Humus UP & $16.4 \mathrm{e}$ & $135 b$ & $100 \mathrm{a}$ & $6.0 \mathrm{~d}-\mathrm{f}$ & 3531 \\
\hline Humus UP + Micosat & $16.8 \mathrm{e}-\mathrm{g}$ & $156 \mathrm{e}-\mathrm{g}$ & $99.5 \mathrm{a}$ & $6.5 f$ & 3451 \\
\hline Humus Active + Aktywit PM & $14.5 b$ & $156 \mathrm{e}-\mathrm{g}$ & $100 \mathrm{a}$ & $5.4 b-d$ & $267 \mathrm{e}$ \\
\hline Humus Active + Aktywit PM + Micosat & $17.4 \mathrm{fg}$ & $166 \mathrm{~h}$ & $100 \mathrm{a}$ & $5.3 \mathrm{bc}$ & 3251 \\
\hline BF Quality & $15.0 \mathrm{~b}-\mathrm{d}$ & $140 \mathrm{bc}$ & $100 \mathrm{a}$ & $6.2 \mathrm{ef}$ & $263 \mathrm{de}$ \\
\hline BF Quality + Micosat & $15.0 \mathrm{~b}-\mathrm{d}$ & $164 \mathrm{gh}$ & $99.8 \mathrm{a}$ & $6.0 \mathrm{~d}-\mathrm{f}$ & $289 \mathrm{gh}$ \\
\hline BF Amin & $14.1 \mathrm{ab}$ & $144 b-d$ & $100 \mathrm{a}$ & $5.8 \mathrm{c}-\mathrm{e}$ & $255 \mathrm{~d}$ \\
\hline BF Amin + Micosat & $16.4 \mathrm{ef}$ & $165 \mathrm{gh}$ & $100 \mathrm{a}$ & $7.5 \mathrm{~g}$ & $299 \mathrm{i}$ \\
\hline Vinassa & $14.4 b$ & $138 b c$ & $100 \mathrm{a}$ & $5.0 \mathrm{~b}$ & $217 b$ \\
\hline Vinassa + Micosat & $15.8 \mathrm{c}-\mathrm{e}$ & $156 f-h$ & $99.5 \mathrm{a}$ & $7.6 \mathrm{~g}$ & 294hi \\
\hline Florovit Eko & $15.1 \mathrm{~b}-\mathrm{d}$ & $151 d-f$ & $100 \mathrm{a}$ & $5.4 b-d$ & $237 \mathrm{c}$ \\
\hline Florovit Eko + Micosat & $16.4 \mathrm{ef}$ & $146 \mathrm{c}-\mathrm{e}$ & $99.8 \mathrm{a}$ & $6.0 \mathrm{~d}-\mathrm{f}$ & $254 d$ \\
\hline
\end{tabular}

Explanations the same as below Table 1. 
Table 4 Effect of various fertilization treatments on plant growth parameters of sour cherry cv. "Debreceni Bötermö" maiden trees grown in an organic nursery, 2012.

\begin{tabular}{|c|c|c|c|c|c|}
\hline Treatment & $\begin{array}{l}\text { Trunk diameter } \\
\mathrm{mm}\end{array}$ & $\begin{array}{l}\text { Tree height } \\
\mathrm{cm}\end{array}$ & $\begin{array}{l}\text { Number of } \\
\text { branched trees } \\
\%\end{array}$ & $\begin{array}{l}\text { Number of } \\
\text { lateral shoots }\end{array}$ & $\begin{array}{l}\text { Total length of } \\
\text { lateral shoots } \\
\mathrm{cm}\end{array}$ \\
\hline Control** & $10.5 \mathrm{a}$ & $116 \mathrm{a}$ & $97.0 \mathrm{a}$ & $2.9 \mathrm{a}$ & $144 a$ \\
\hline Micosat & $13.9 \mathrm{ef}$ & $133 \mathrm{de}$ & $98.8 \mathrm{a}$ & $4.4 b c$ & $186 b$ \\
\hline NPK & $12.7 \mathrm{bc}$ & $130 \mathrm{~cd}$ & $99.8 \mathrm{a}$ & $6.5 \mathrm{gh}$ & $270 \mathrm{~h}$ \\
\hline NPK + Micosat & $10.2 \mathrm{a}$ & $121 \mathrm{ab}$ & $99.0 \mathrm{a}$ & $4.0 \mathrm{~b}$ & $154 \mathrm{a}$ \\
\hline Fertigo Manure & $12.2 b$ & $125 \mathrm{bc}$ & $100 \mathrm{a}$ & $4.8 \mathrm{~cd}$ & $248 \mathrm{ef}$ \\
\hline Fertigo Manure + Micosat & $12.7 b-d$ & $131 \mathrm{c}-\mathrm{e}$ & $99.8 \mathrm{a}$ & $4.8 \mathrm{~cd}$ & $261 \mathrm{gh}$ \\
\hline Humus UP & $12.5 b$ & $136 \mathrm{~d}-\mathrm{f}$ & $100 \mathrm{a}$ & $6.2 \mathrm{f}-\mathrm{h}$ & $351 \mathrm{k}$ \\
\hline Humus UP + Micosat & $12.3 b$ & $121 \mathrm{ab}$ & $99.5 \mathrm{a}$ & $5.1 \mathrm{de}$ & $210 \mathrm{c}$ \\
\hline Humus Active + Aktywit PM & $13.8 \mathrm{~d}-\mathrm{f}$ & $141 \mathrm{f}$ & $100 \mathrm{a}$ & $7.3 \mathrm{i}$ & $301 \mathrm{i}$ \\
\hline Humus Active + Aktywit PM + Micosat & $14.0 \mathrm{f}$ & $137 \mathrm{ef}$ & $99.5 \mathrm{a}$ & $9.0 \mathrm{k}$ & $338 \mathrm{j}$ \\
\hline BF Quality & $13.7 \mathrm{c}-\mathrm{f}$ & $135 d-f$ & $100 \mathrm{a}$ & 6.6hi & $299 \mathrm{i}$ \\
\hline BF Quality + Micosat & $12.2 \mathrm{~b}$ & $125 \mathrm{bc}$ & $100 \mathrm{a}$ & $8.0 \mathrm{j}$ & $307 \mathrm{i}$ \\
\hline BF Amin & $12.3 b$ & $131 \mathrm{c}-\mathrm{e}$ & $100 \mathrm{a}$ & $4.8 \mathrm{~cd}$ & $223 \mathrm{~cd}$ \\
\hline $\mathrm{BF}$ Amin + Micosat & $14.8 \mathrm{f}$ & $132 \mathrm{c}-\mathrm{e}$ & $99.3 \mathrm{a}$ & $8.0 \mathrm{j}$ & $311 \mathrm{i}$ \\
\hline Vinassa & $12.9 \mathrm{~b}-\mathrm{e}$ & $129 \mathrm{~cd}$ & $100 \mathrm{a}$ & $5.8 \mathrm{e}-\mathrm{g}$ & $253 \mathrm{fg}$ \\
\hline Vinassa + Micosat & $12.8 \mathrm{~b}-\mathrm{e}$ & $121 \mathrm{ab}$ & $100 \mathrm{a}$ & $5.6 \mathrm{ef}$ & $269 \mathrm{~h}$ \\
\hline Florovit Eko & $12.2 b$ & $125 b c$ & $100 \mathrm{a}$ & $4.7 b-d$ & $221 \mathrm{c}$ \\
\hline Florovit Eko + Micosat & $12.6 \mathrm{bc}$ & $120 \mathrm{ab}$ & $100 \mathrm{a}$ & $7.3 \mathrm{i}$ & $235 \mathrm{de}$ \\
\hline
\end{tabular}

Explanations the same as below Table 1.

branched maidens, but significantly stimulated an increase in the number of lateral shoots, except for combinations with NPK and Humus UP.

\section{Discussion}

The scientific literature contains many reports on the effects of mycorrhizal fungi on growth and fruiting of horticultural crops such as strawberry [1, 2, 8-10]. Very few publications are available on the effect of mycorrhiza on growth and development of rootstocks and young fruit trees in organic nurseries, and later in orchards [4, 6, 16, 17]. Symbiosis between crop plants and mycorrhizal fungi is commonly known to exist. There is little information available on the effectiveness of mycorrhization in the presence of a specific group of organic fertilizers, or mineral fertilizers. No one questions that young trees in organic nurseries need nutrients for growth [14, 17]. Explanation is required, however, whether there is synergism or antagonism between the positive action of mycorrhizal fungi and that of a specific type of biofertilizers, or perhaps an indifferent response by plants to their presence $[3,10]$. Only a partial answer to this question is given by the results of the present work. When mineral fertilization was used, the effectiveness of mycorrhizal fungi in the nursery of maiden apple trees was low or almost undetectable. This effect had been confirmed by previous studies carried out at the Research Institute of Horticulture in Skierniewice. Sas Paszt et al. [2] showed negative effects of NPK fertilization on the formation of mycorrhizas on the roots of fruit plants and the reduction in biodiversity and populations of beneficial soil microflora. Thus the low effectiveness of mycorrhiza is caused by the negative effect of NPK fertilization on the development of soil microflora and by the sufficient availability of NPK minerals under mineral fertilization. The effectiveness of mycorrhiza was also negligible when vermiculite (Humus UP) was used as a fertilizer. On the other hand, in the presence of manure or biopreparations such as $\mathrm{BF}$ Amin or Vinassa, stimulation of growth of young trees 
under the influence of mycorrhiza was clearly evident, which is consistent with previous studies conducted by Grzyb et al. [13, 21] and Sas Paszt et al. [2]. Mycorrhization had no effect on the growth of sour cherry maidens in the presence of the fertilizer Florovit Eko. In apple, by contrast, the joint action of mycorrhization and Florovit Eko, in terms of the intensity of tree growth and development, was significant.

There are reports in literature how the quality of trees at planting affects their subsequent growth and fruiting $[15,22,23]$. The reports emphasize that young trees to be used for establishing an orchard should have a specific height and trunk thickness, and be adequately branched. The authors state that trees already branched in the nursery produce flower buds early in the orchard, and thus guarantee high yields. They agree that every one-metre length of lateral branches bears two kilograms of apples in the second year after planting. In practice, the productivity is generally greater than $2 \mathrm{~kg}$ of apples per $1 \mathrm{~m}$ of lateral branches. Young trees for planting should thus not only be branched, but also have a sufficiently large number and overall length of lateral branches.

The authors' own studies have shown that mycorrhization in the soil environment does not always enhance the biological activity of the biopreparations used. It should also be mentioned that the resulting positive effects may differ considerably in different species of fruit trees. Application of mycorrhizal fungi can, however, be a factor contributing to the overall development of fruit plants, especially during their propagation in the organic nursery $[14,21]$.

Studies and observations carried out at the Research Institute of Horticulture in Skierniewice indicate much greater effectiveness of mycorrhization in plantings of young plants in the early stages of vegetative growth than in the later stages of their growth [2].

In the next stage of research, particular attention will be paid to the impact of treatments used in the nursery on the development of the root system maidens organically grown.

\section{Conclusions}

Micosat markedly stimulates the growth and development of apple ('Topaz'/M 26) and sour cherry ('Debreceni Bötermö'Prunus mahaleb) maiden trees in the organic nursery.

The effect of the mycorrhizal preparation Micosat on the development of maiden apple and sour cherry trees previously fertilized with mineral fertilizers (NPK) is not significant.

In combination with organic fertilization, the presence of Micosat favours the development of apple and sour cherry maidens. The most effective in this process are: for apple-Fertigo granular manure, Vinassa and Florovit Eko, and for sour cherry-BF Quality, BF Amin and Humus Active + Aktywit PM.

\section{Acknowledgments}

The work has been supported by a grant from the EU Regional Development Fund through the Polish Innovation Economy Operational Programme, contract N. UDA-POIG.01.03.01-10-109/08-00.

\section{References}

[1] Malusa, E., Sas Paszt, L., Popińska, W., and Żurawicz, E. 2007. "The Effect of a Substrate Containing Arbuscular Mycorrhizal Fungi and Rhizosphere Microorganisms (Trichoderma, Bacillus, Pseudomonas and Streptomonas) and Foliar Fertilization on Growth Response and Rhizosphere $\mathrm{pH}$ of Three Strawberry Cultivars." Intern. $J$. Fruit Sci. 6: 25-41.

[2] Sas Paszt, L., Sumorek, B., Malusa, E., Głuszek, S., and Derkowska, E. 2011. "The Influence of Bioproducts on Root Growth and Mycorrhizal Occurrence in the Rhizosphere of Strawberry Plants 'Elsanta'." J. Fruit Ornam. Plant Res. 19 (1): 13-34.

[3] Azcon-Aguilar, C., and Barea, J. M. 1997. “Applying Mycorrhiza Biotechnology to Horticulture Significance and Potentials." Sci. Hort. 68: 1-24.

[4] Calvet, C., Estaún, V., Camprubi, A., Hernandez-Dorrego, A., Pinochet, J., and Angeles-Moreno, M. 2004. "Aptitude for Mycorrhizal Root Colonization in Prunus Rootstocks." Sci. Hort. 100: 39-49. 
[5] Estaun, V., Calvet, C., and Camprubi, A. 1994. "Arbuscular Mycorrhiza and Growth Enhancement of Micropropagated Prunus Rootstock in Different Soilless Potting Mixes." Agric. Sci. Finland 3: 263-7.

[6] Lovato, P. E., Trouvelot, A., Gianinazzi-Pearson, V., and Gianinazzi, S. 2006. "Enhanced Growth of Wild Cherry Using Micropropagated Plants and Mycorrhizal Inoculation." Agron. Sustain. Dev. 26: 209-13.

[7] Yilmaz, N., Çetiner, S., and Ortas, I. 2009. "The Effects of the Mycorrhiza on Plant Growth During Acclimatization of Some In vitro Grown Sweet Cherry Rootstocks." Sabanci Univ. 13253: 1-10. http://research.sabanciuniv.edu/13253/.

[8] Didier, M. F., Hamel, C., Dalpe, Y., and Kanizadeh, S. 2003. "Diversity of Native Endomycorrhizal Fungi in Selected Strawberry Field Soils of Southern Quebeck." Small Fruits Review 2: 61-71.

[9] Sas Paszt, L., and Zurawicz, E. 2004. "The Influence of Nitrogen Forms on Root Growth and $\mathrm{pH}$ Changes in the Rhizosphere of Strawberry Plants." Acta Hort. 649: 217-21.

[10] Yin, B., Wang, Y., Liu, P., and Hu, J., W. 2010. "Effects Vesicular-Arbuscular Mycorrhizal on the Protective System in Strawberry Leaves under Drought Stress." Front. Agric. China 4: 165-9.

[11] Chelariu, E. L., Draghia, L., Bireescu, G., Bireescu, L., and Branza, M. 2009. "Research Regarding the Influence of Vinassa Fertilization on Gomphrena globosa Species." Lucr. stiintifice, Ed. Ion Ionescu de la Brad, Iasi Usamviasi, Seria Hort. 52: 615-20.

[12] Khan, W., Rayirath, U. P., Subramanian, S., Jithesh, M. N., Rayorath, P., Hodges, D. M., Critchley, A. T., Craigie, J. S., Norrie, J., Prithiviraj, B. 2009. "Seaweed Extracts as bio Stimulants of Plant Growth and Development." $J$. Plant Growth Regul. 28: 386-99.

[13] Grzyb, Z. S., Bielicki, P., Piotrowski, W., Sas Paszt, L., and Malusa, E. 2012 (a). "Effect of Some Organic Fertilizers and Amendments on the Quality of Maidens Trees of Two Apple Cultivars." In Proceedings of the 15th Intern. Confer. on Organic Fruit Growing, 410-4.

[14] Grzyb, Z. S., Piotrowski, W., Bielicki, P., Sas Paszt, L., and Malusa, E. 2013 (a). "Effect of Organic Fertilizers and Soil Conditioners on the Quality of Apple Maiden Trees." Acta Hort. 1001: 311-21.

[15] Bielicki, P., Czynczyk, A., and Nowakowski, S. 2002. "Influence of Plant Material Quality on Growth and Field of Two Apple Cultivars." Horticulture and Veget. Growing 21 (4): 33-8.

[16] Świerczyński, S., and Stachowiak, A. 2010. "The Influence of Mycorrhizal Fungi on the Growth and Yielding of Plum and Sour Cherry Trees." J. Fruit Ornam. Plant Res. 18 (2): 71-7.

[17] Stachowiak, A., and Świerczyński, S. 2009. "The Influence of Mycorrhizal Vaccine on the Growth of Maiden Sweet Cherry Trees of Selected Cultivars in Nursery." Acta Sci. Pol. Hortorum Cultus 8 (1): 3-11.

[18] Aka-Kacar, Y., Akpinar, C., Agar, A., Yalcin-Mendi, Y., Serce, S., and Ortas, I. 2010. "The Effect of Mycorrhiza in Nutrient Uptake and Biomass of Cherry Rootstocks during Acclimatization." Rom. Biotech. Lett. 15 (3): 5246-52.

[19] Grzyb, Z. S., Piotrowski, W., Sas Paszt, L., and Bielicki, P. 2013 (b). "The Quality of Sour Cherry Maidens Fertilized with Various Biopreparations in the Organic Nursery." J. Life Sci. USA 7 (4): 400-9.

[20] Grzyb, Z. S., Piotrowski, W., Sas Paszt, L., and Pąśko, M. 2013 (c). "Levels of Acidity and Mineral Elements in the Soil and Leaves of Maidens Apple and Sour Cherry Trees Treated with Different Bioproducts in an Organic Nursery-Preliminary Results." J. Res. Applic. Agric. Engineering Poznań 58 (3): 198-203 (in Polish).

[21] Grzyb, Z. S., Piotrowski, W., Bielicki, P., Sas Paszt, L., and Malusa, E. 2012 (b). "Effect of Different Fertilizers and Amendments on the Growth of Apple and Sour Cherry Rootstock in an Organic Nursery." J. Fruit Ornam. Plant Res. 20 (1): 43-53.

[22] Shepherd, H. R. 1979. "Effect of Tree Quality at Planting on Orchard Performance." Annu. Rep. East Malling Res. St. for 1978: 40.

[23] Mika, A., Buler, Z., and Krawiec, A. 2003. "Effects of Various Methods of Pruning Apple Trees after Planting." J. Fruit Ornam. Plant Res. 11: 33-43. 